\title{
Pengaturan Lampu Lalu Lintas Secara Nirkabel Bertenaga Surya
}

\author{
Nanang Warihandoko, Muhammad Rivai, dan Tasripan, \\ Jurusan Teknik Elektro, Fakultas Teknologi Industri, Institut Teknologi Sepuluh Nopember (ITS) \\ Jl. Arief Rahman Hakim, Surabaya 60111 \\ e-mail:muhammad_rivai@ee.its.ac.id, tasripan@ee.its.ac.id, nanang14@mhs.ee.its.ac.id
}

\begin{abstract}
Abstrak-Lampu lalu lintas merupakan sarana yang sangat penting untuk mengatur kendaraan yang melintasi persimpangan. Tetapi pada lampu lalu lintas tersebut banyak terdapat permasalahan, misalnya masalah kondisi persimpangan dekat sungai, dekat perlintasan kereta api atau persimpangan tidak simetris sehingga penggunaan kabel sebagai komunikasi tidak efektif digunakan. Oleh karena itu pada penelitian ini telah dikembangkan sebuah sistem kontrol lampu lalu lintas secara nirkabel menggunakan perangkat $\mathrm{Xbee} 2.4 \mathrm{Ghz}$ dengan topologi jaringan point to multipoint untuk komunikasi antara kontrol utama lampu lalu lintas dengan setiap lampu lalu lintas di persimpangan. Sistem ini menggunakan ip camera untuk mengetahui kepadatan setiap persimpangan sehingga dapat mengatur waktu hijau secara efektif. Algoritma haar cascade clasifier digunakan untuk menghitung jumlah kendaraan di setiap persimpangan dan memberikan input ke kontrol utama lampu lalu lintas untuk mengatur lama waktu hijau. Sistem dilengkapi dengan monitoring via web server menggunakan thingspeak.com untuk mengetahui tegangan yang tersimpan di baterai. Pengujian dilakukan dengan meletakkan setiap lampu dengan jarak 100 meter dari kontrol utama lampu lalu lintas. Untuk penggunaan Baterai 50 AH dengan beban lampu lalu lintas dan modul $x b e e$ dapat digunakan selama 8 hari tanpa pengisian. Penentuan waktu hijau efektif di simpang empat adalah antara 15 detik sampai 28 detik untuk setiap banyak antrian kendaraan, dengan kesalahan deteksi kendaraaan dalam kondisi antrian adalah $45 \%$.
\end{abstract}

Kata kunci-Haar cascade classifier, Ip camera, Komunikasi nirkabel, Lampu lalu lintas, Xbee.

\section{PENDAHULUAN}

$\mathrm{L}$ AMPU lalu lintas merupakan perangkat yang penting dan sangat di butuhkan di setiap kota. Lampu lalu lintas adalah lampu untuk mengendalikan arus lalu lintas yang terpasang di persimpangan jalan, tempat penyeberangan pejalan kaki, dan tempat arus lalu lintas lainnya.Lampu ini yang menandakan kapan kendaraan harus berjalan dan berhenti secara bergantian dari berbagai arah. Pengaturan lalu lintas di persimpangan jalan dimaksudkan untuk mengatur pergerakan kendaraan pada masing-masing kelompok pergerakan kendaraan agar dapat bergerak secara bergantian sehingga tidak saling mengganggu antar arus yang ada. Sudah banyak tipe pengaturan lampu lalu lintas yang telah diterapkan mulai dari menggunakan sumber tenaga langsung dari PLN ada juga yang menggunakan tenaga surya sebagai upaya untuk penghematan energi. Tapi kebanyakan pengaturan lampu lalu lintas yang telah terpasang masih menggunakan kabel bawah tanah untuk mengubungkan lampu yang telah terpasang di setiap persimpangan dengan kontrol utamanya sehingga dalam pemasangannya sangat rumit karena akan membutuhkan kabel yang banyak dan panjang dan membutuhkan waktu untuk melakukan pengeboran aspal. Oleh karena itu dalam penelitian ini telah di rancang model lampu lalu lintas yang menggunkan komunikasi nirkabel untuk mengantikan kabel untuk menyalakan lampu di setiap persimpangannya. Komunikasi nirkabel dirancang menggunakan topologi point to multipoint karena digunakan satu kontrol sebagai master dan lampu yang terpasang di tiang di setiap persimpangan sebagai node. Jalur protokol komunikasi nirkabel yang digunakan adalah zigbee, dengan perangkat yang diguankan adalah modul Xbee-Pro. Modul Xbee atau ZigBee ini menggunakan komunikasi serial dengan modulasi FSK (Frequency Shift Keying) dengan frekuensi 2.4 GHz. Jangkauan Xbee mencapai 30 meter indoor dan 100 meter outdoor, sedangkan Xbee-Pro 100 meter indoor dan 1500 meter outdoor [1]. Tentunya jangkauan tersebut akan lebih efektif jika menggunakan antena khusus Xbee atau menggunkan eksternal antena, Xbee juga merupakan salah satu modul telemetri yang dapat berfungsi sebagai RX dan TX sekaligus atau dapat melakukan komunikasi dua arah.

Data sistem monitoring tegangan baterai pada lampu lalu lintas akan dikirim ke sebuah web server menggunakan thingspeak.com API (Application Programming interface), yang akan menampilkan data berupa grafik dan menyimpan secara berkala.

\section{METODE PENELITIAN}

\section{A. Perancangan Sistem}

Kontrol utama lampu lintas bekerja dengan 2 mode, yaitu manual dengan waktu hijau ditentukan dan disimpan di memori EEPROM untuk waktu nyala setiap persimpangan bergantian, mode yang kedua adalah dengan menambahkan input kamera untuk mendeteksi kepadatan disetiap simpang untuk memberikan waktu hijau efektif. Diagram blok sistem secara keseluruhan ditunjukkan pada Gambar 1.
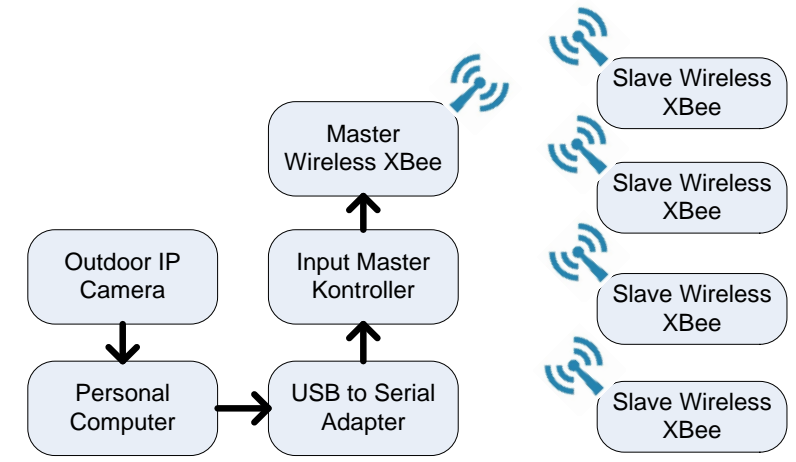

Gambar 1. Blok diagram keseluruhan 


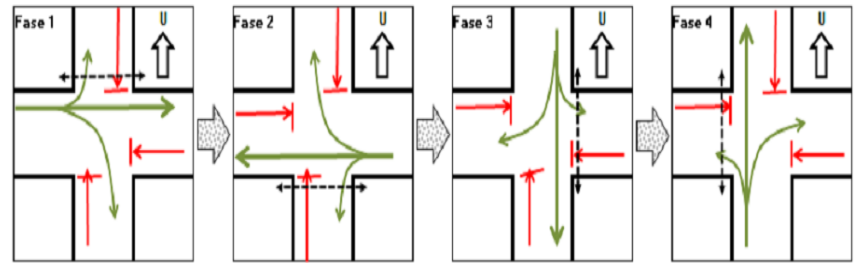

Gambar 2. Tipe Pengaturan 4 fase

\section{B. Perancangan Perangkat APILL}

APILL (Alat Pemberi Isyarat Lalu Lintas) adalah alat yang mengatur arus lalu lintas menggunakan 3 isyarat lampu yang baku, yaitu merah, kuning, dan hijau. Penggunaan 3 warna tersebut bertujuan memisahkan lintasan arus lalu lintas yang saling konflik dalam bentuk pemisahan waktu berjalan. Dalam penelitian ini di pilih tipe simpang menggunakan simpang 4 dengan pengaturan fase tipe 44B [2], seperti pada gambar 2. yaitu setiap fase berjalan bergantian dan tidak di bedakan antara kendaraan jalan lurus, kendaraan belok kanan dan kendaraan belok kiri.

Berikut ini merupakan parameter-parameter dalam penentuan waku isyarat [2]:

- Kondisi geografis simpang.

- Rasio kendaraan yang lurus, belok kiri, dan belok kanan.

- Arus jenuh dasar di setiap fase.

- Kapasitas simpang.

- Panjang dan jumlah antrian.

- Waktu siklus untuk simpang 4 antara 80 detik - 130 detik.

Dengan asumsi mengidealkan setiap kondisi parameter dan hanya melihat antrian kendaraan setiap fase untuk penentuan waktu isyarat hijau berdasarkan waktu siklus antara 80 detik 130 detik, maka dapat dihitung waktu isyarat hijau minimal dan maksimal setiap fase. Dengan perhitungan banyak antrian dengan persamaan 1 di bawah ini.

$N_{Q}=N_{Q 2}=t_{\text {siklus }} \times \frac{\left(1-R_{\text {Hijau }}\right)}{\left(1-R_{\text {Hijau }} \times D_{J}\right)} \times \frac{Q}{3600}$

\section{Perangkat master dan slave Xbee}

$X$-Bee Pro dirancang agar dapat memenuhi teknologi ZigBee/IEEE 802.15.4. ZigBee/IEEE 802.15.4 yang berhubungan dengan Wireless Personal Area Networks (WPANs) teknologi yang memfokuskan data rate rendah, konsumsi daya rendah, biaya rendah, target protokol jaringan wireless untuk aplikasi otomasi dan kendali remote. Zigbee mempunyai kecepatan transmisi sekitar $250 \mathrm{Kbps}$, Zigbee bekerja pada frekuensi 2,4 GHz, $868 \mathrm{MHz}$ dan $915 \mathrm{MHz}$, dimana ketiga rentang frekuensi ini merupakan rentang frekuensi yang gratis [3].

Perancangan kontroller master slave untuk wireless Xbee menggunakan mikrokontroller AVR dengan tipe ATmega328, dikarenakan ATmega328 sudah dapat diisikan program bootloader sehingga apabila memasukkan program ke IC tidak perlu menggunakan tipe downloader dengan komunikasi SPI (Serial Programming Interface) atau JTAG (Joint Test Action Group) karena dengan adanya bootloader program dapat dimasukkan ke memori flash mikrokontroller melalui komunikasi serial, disini dirancang menggunakan modul FTDI
(Future Technology Devices International) untuk upload program dari komputer ke mikrokontroller.

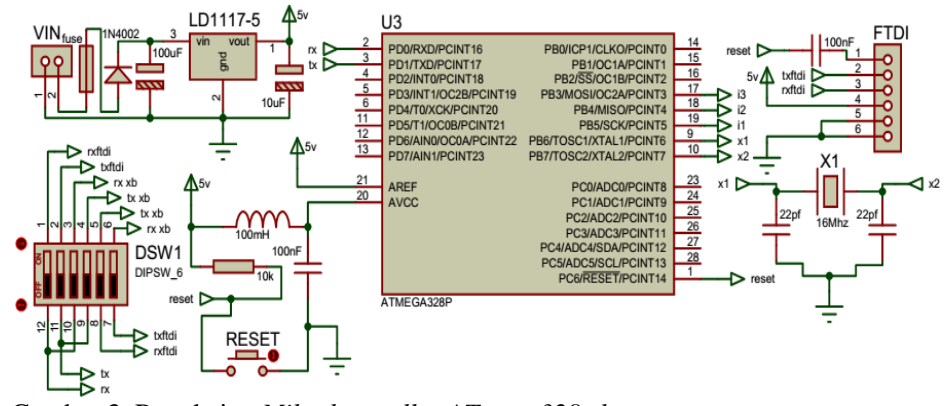

Gambar 3. Rangkaian Mikrokontroller ATmega328 slave

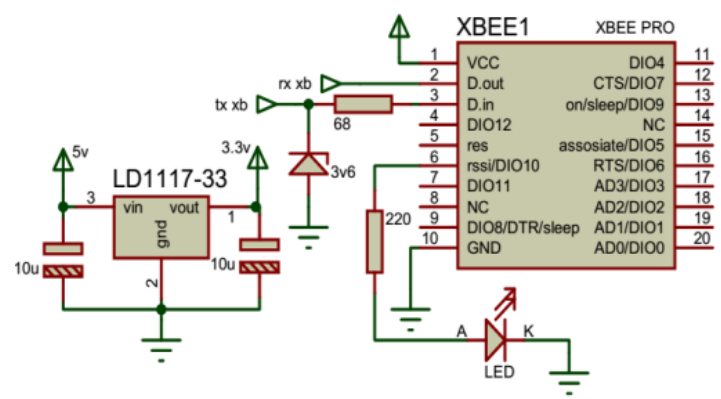

Gambar 4. Rangkaian Modul Xbee-Pro

Rangkaian mikrokontroller Atmega328 dapat dilihat pada gambar 3. Radio frequency transceiver yang digunakan adalah tipe XBP24-AUI-001 Xbee-Pro Zigbee module w/ U. FL Connector dengan frekuensi 2.4 Ghz. Radio frequency transceiver ini merupakan sebuah modul yang terdiri dari RF receiver dan RF transmiter dengan system interface serial UART 3.3V. Xbee Pro bekerja pada tegangan catu 3.3V sehingga di butuhkan regulator tegangan. Rangkaian modul Xbee-pro dapat dilihat pada gambar 4.

\section{Perancangan Traffic Light Controller}

Traffic Light Controller merupakan perangkat yang digunakan sebagai kontrol utama dalam pengaturan lampu lalu lintas baik menggunakan kabel ke setiap tiangnya maupun secara nirkabel. Dalam penelitian ini perancangan traffic light controller menggunakan mikrokontroller ATmega2560 yang dilengkapi dengan beberapa perangkat penunjang controller seperti: keypad digunakan untuk memasukkan nilai pengaturan ke dalam mikrokontroller, LCD TFT digunakan untuk menampilkan setiap pengaturan di dalam traffic light controller, RTC digunakan untuk mengambil waktu, switch input digunakan untuk mengganti mode dari traffic light controller dari mode run manual, run dari input kamera, run kedip, dan setting pengaturan lampu lalu lintas. Blok diagram dari traffic light controller keseluruhan dapat dilihat pada gambar 5 di bawah ini. 


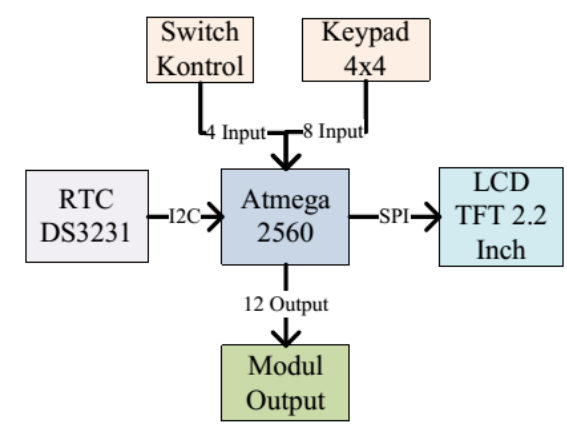

Gambar 5. Blok diagram traffic light controller

Pada komunikasi ATmega2560 dengan LCD TFT menggunakan level tegangan konverter dengan IC digital tipe CD4050, dikarenakan untuk komunikasi SPI pin output dari ATmega2560 memiliki level tegangan 5V sedangkan untuk komunikasi SPI dari LCD TFT mempunyai level tegangan 3.3V

\section{E. Perancangan Modul Wireless ESP8266}

Modul Wireless ESP8266 digunakan sebagai client yang terkoneksi ke jaringan internet dari wireless router, karena ESP8266 merupakan mikrokontroller yang sudah terdapat koneksi wireless dalam satu chip maka terdapat juga peripheral ADC (Analog digital Converter) digunakan untuk membaca nilai tegangan dari baterai solar cell dan dikirim data tegangan ke web thingspeak.com sebagai monitoringnya. ADC ESP8266 memiliki resolusi 10 bit dengan maksimal tegangan input $1 \mathrm{~V}$, sehingga untuk membaca tegangan baterai solar cell dibutuhkan rangkaian pembagi tegangan. Gambar 6 merupakan rangkaian interface dari modul wireless ESP8266.

Dalam penulisan program ESP8266 menggunakan Arduino IDE dengan menambahkan board manager ke Arduino IDE, sehingga. Semua pin input output akan compatible dengan Arduino, untuk meng-upload program digunakan FTDI modul yang terkoneksi ke pin serial transmit dan receive. Tegangan level converter ditambahkan jika level tegangan serial dari FTDI modul adalah $5 \mathrm{~V}$ karena tegangan level dari modul ESP8266 adalah 3.3V menggunakan diode zener. Jumper selPROG digunakan sebagai selector modul ESP8266 dapat di uploadkan program dari Arduino IDE dan untuk kondisi berjalannya program. Rangkaian pembagi tegangan digunakan untuk membagi tegangan yang masuk ke pin ADC, seperti pada gambar 7. Sehingga apabila dihitung tegangan masuk pin ADC dengan input maksimal tegangan baterai $15 \mathrm{~V}$ adalah sebagai berikut.

$V_{A D C}=\frac{R 3}{(R 1+R 2)+R 3} \times V_{b a t}$

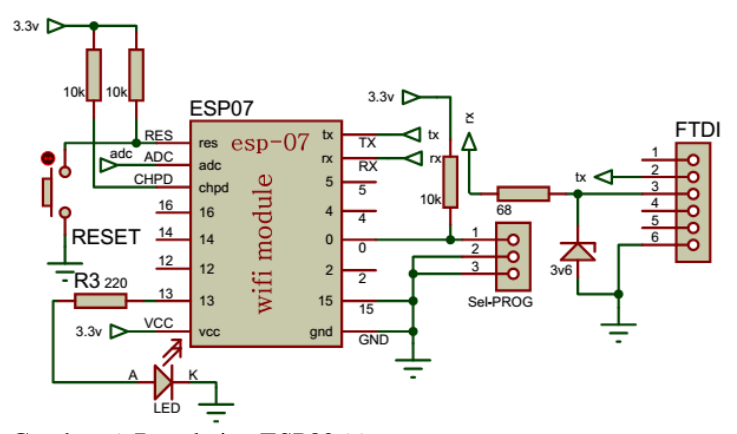

Gambar 6. Rangkaian ESP8266

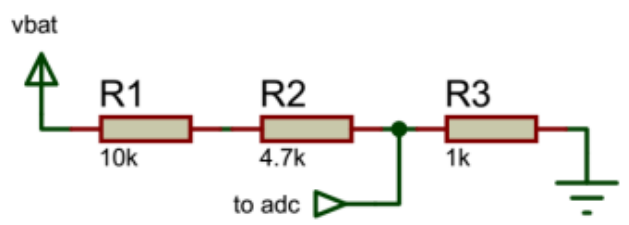

Gambar 7. Rangkaian Pembagi Tegangan

\section{F. Perancangan Lampu Lalu Lintas}

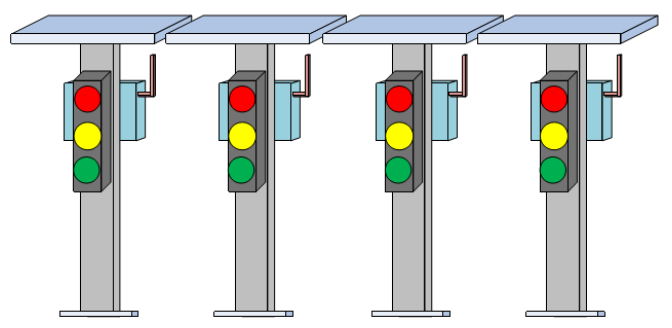

Gambar 8. Perancangan lampu lintas nirkabel

Perancangan lampu lintas merupakan desain dan implementasi lampu lalu lintas menggunakan led dengan tegangan kontrol 12 Volt dan ukuran diameter PCB lampu adalah $20 \mathrm{~cm}$ untuk setiap box lampu, dalam pemasangan lampu lalu lintas sumber tegangan di dapat dari baterai yang dapat di isi ulang menggunakan panel surya yang telah terpasang di setiap tiang. Gambar 8 dibawah ini merupakan gambar dari implementasi pemasangan lampu lalu lintas nirkabel.

\section{G. Perancangan Software Master dan Slave}

Dalam perancangan software master dan slave wireless xbee meliputi pengaturan Xbee dengan xctu untuk melakukan pengaturan pada Xbee seperti pemberian nomor alamat ID dan penggunaan API (Application Programming Interface) mode sebagai mode operasi dari Xbee. Pengaturan topologi jaringan dari Xbee menggunakan topologi point to multipoint dengan perangkat pengirim disebut master dan perangkat penerima disebut slave. Setelah pengaturan menggunakan xctu perangkat xbee akan dihubungkan secara serial ke mikrokontroller ATmega328 dengan pemrograman untuk pembacaan data dari kontrol utama lampu lalu lintas, pengiriman data, penerimaan data dan kontrol lampu menggunakan Arduino IDE, gambar 9 merupakan flowchart dari master controller sebagai pengirim data ke setiap slave.

Deklarasi alamat ID digunakan untuk memasukkan alamat tujuan pengiriman yaitu alamat ID dari setiap node atau slave. Baca 12 input merupakan proses membaca 12 pin input digital dari output kontrol utama lampu lalu lintas. Selanjutnya adalah membagi 12 pin input menjadi 4 bagian untuk setiap bagian ada 3 kontrol untuk lampu merah, hijau dan kuning. Setelah membagi menjadi 4 bagian selajutnya adalah mengirim data 3 kontrol tersebut ke ID address masing-masing slave atau node dengan mode pengiriman 16-bit addressing. 


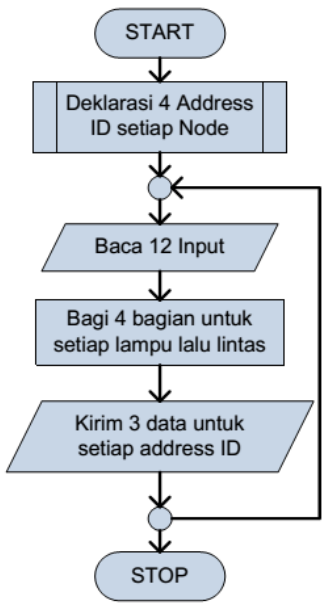

Gambar 9. Flowchart master wireless xbee

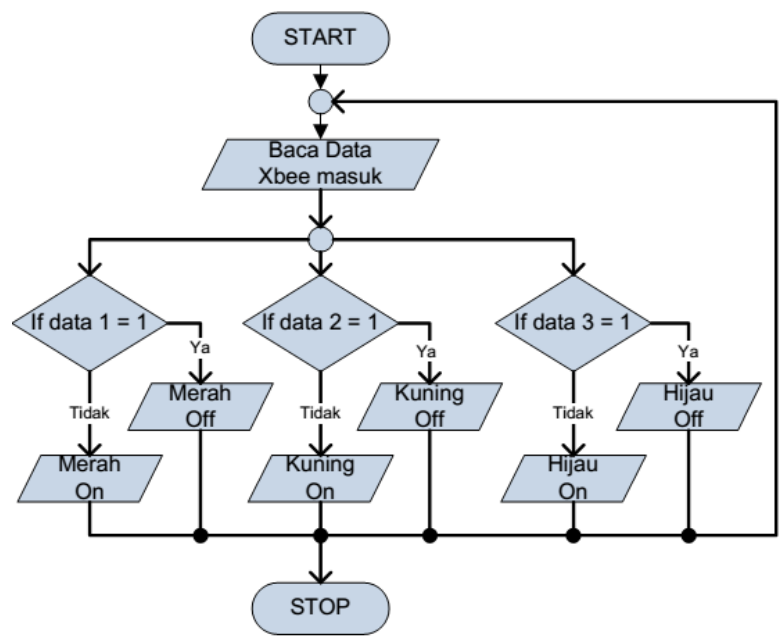

Gambar 10. Flowchart slave wireless untuk kontrol lampu

Setelah semua perangkat terkoneksi, antara master dan masing-masing slave dengan indikasi lampu dari RSSI menyala, selanjutnya Xbee dari tiap slave akan menerima paket data dari master. 3 data yang ditelah diterima akan di ambil sesuai flowchart pada gambar 10, yaitu satu data digital untuk kontrol lampu merah, satu data digital untuk kontrol lampu kuning dan satu data digital untuk kontrol lampu hijau. Perangkat Xbee akan menerima data dari master secara terusmenerus (continue).

\section{H. Software Deteksi Kendaraan}

Perancangan Software deteksi kendaraan menggunakan library opencv sebagai media untuk pemrosesan gambar. Dan untuk algoritma pendeteksi menggunakan haar cascade classifier yang telah ada di library opencv dan image di dapat dari hasil konversi video dari ip camera menjadi tipe MJPEG (MotionJPEG). Perancangan software menggunakan Processing IDE 3.0 yang merupakan multi platform programming berbasis java yang dapat di jalankan di sistem operasi windows, linux dan mac. Gambar 11 berikut ini merupakan perancangan flowchart dari cara pendektesian menggunakan haar cascade classifier [4].

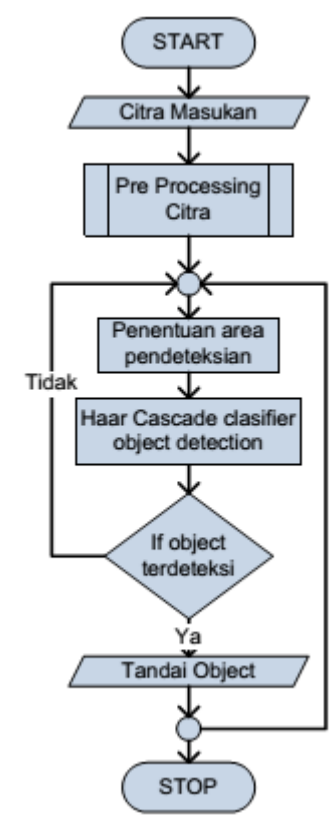

Gambar 11. Pendeteksian Obyek dengan Haar Cascade Clasifier

Proses haar cascade classifier merupakan proses membandingkan input gambar yang masuk dengan database gambar yang telah di lakukan learning, apabila nilai input gambar diatas nilai dari threshold yang telah ditentukan maka gambar akan ditandai dengan rectangular dan ditentukan sebagai kendaraan, dan apabila nilai di bawah nilai threshold maka gambar input bukan merupakan kendaraan jadi tidak di tandai [5].

\section{PENGUJIAN DAN PEMBAHASAN}

\section{A. Pengukuran Tegangan Dan Arus Pada Node Kondisi Mengirim Paket Data}

Pengujian dilakukan dengan memberikan tegangan pada supply sebesar $12 \mathrm{~V}$. Node yang digunakan adalah node dengan konsumsi arus sebesar $90 \mathrm{~mA}$ pada kondisi idle. Node diberikan program pengiriman paket data "0123456789" sebanyak 50 kali kepada modul Xbee Pro yang tehubung dengan laptop melalui USB to TTL. Pengujian diawali dengan penekanan huruf ' $R$ ' pada Xbee Pro yang terhubung dengan laptop dengan tujuan untuk mengawali paket data yang akan dikirim. Selanjutnya arus konsumsi di node akan di ukur menggunakan multimeter dengan jarak pengiriman yang berbeda-beda antara xbee pro di node dengan xbee pro yang terhubung ke laptop.

Pengiriman paket data dengan jarak yang bervariasi memberikan konsumsi arus yang berbeda. Terlihat pada Tabel 1, pada jarak pengiriman 10-50 meter, arus yang dikonsumsi sebesar $100 \mathrm{~mA}$ atau terjadi kenaikan $10 \mathrm{~mA}$ dari kondisi idle. Pada jarak 60-80 meter arus yang dikonsumsi sebesar $120 \mathrm{~mA}$ atau terjadi kenaikan $30 \mathrm{~mA}$ dari kondisi idle. Dan pada jarak 90-100 meter arus yang dikonsumsi sebesar $140 \mathrm{~mA}$ atau terjadi kenaikan $50 \mathrm{~mA}$ dari kondisi idle. Sehingga dapat dikatakan bahwa semakin jauh jarak pengiriman maka konsumsi arus node adalah sama atau makin tinggi. 
Tabel 1.

Pengukuran Tegangan dan arus Node saat pengiriman paket data

\begin{tabular}{ccc}
\hline \hline Jarak $(\mathrm{m})$ & Tegangan $(\mathrm{v})$ & Arus $(\mathrm{mA})$ \\
\hline 10 & 5.02 & 100 \\
20 & 5.02 & 100 \\
30 & 5.02 & 100 \\
40 & 5.02 & 100 \\
50 & 5.02 & 100 \\
60 & 5.02 & 120 \\
70 & 5.02 & 120 \\
80 & 5.02 & 120 \\
90 & 5.02 & 140 \\
100 & 5.02 & 140 \\
\hline \hline
\end{tabular}

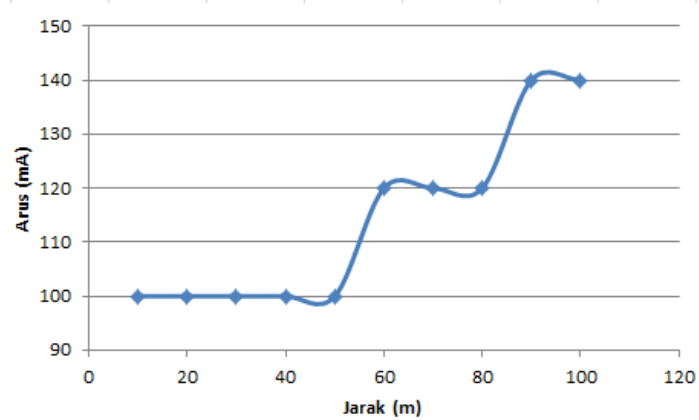

Gambar 12 Pengujian besar arus node terhadap jarak pengiriman data

Pada kondisi setelah pengiriman, arus yang dikonsumsi adalah $90 \mathrm{~mA}$ atau kembali pada kondisi idle. Sehingga apabila Xbee melaukan pengirman langsung dan terus menerus dari master ke setiap node (slave) dapat dihitung konsumsi arus untuk jarak efektif setiap node ke master adalah 100 meter, maka konsumsi daya baterai dan daya tahan baterai dapat di hitung sebagai berikut.

$$
\begin{aligned}
& \mathrm{P}=\mathrm{V} \times \mathrm{I} \\
& \mathrm{P}=5.03 \mathrm{~V} \times 140 \mathrm{~mA} \\
& \mathrm{P}=0.704 \text { watt }
\end{aligned}
$$

Karena xbee pro dan mikrokontroller tidak dalam mode sleep karena aktif terus menerus dalam kurun waktu 1x24 jam maka daya yang dihabiskan adalah 0.452 watt x 24 jam. Sehingga daya yang dihabiskan sebesar 16.896 watt. Dengan menggunakan baterai berdaya $12 \mathrm{~V}, 50 \mathrm{Ah}$, maka node di supply selama $50 \mathrm{Ah} / 140 \mathrm{~mA}=357.14 \mathrm{jam}=14.8$ hari

\section{B. Pengujian Software Deteksi Kendaraan}

Pengujian perangkat lunak disini merupakan pengujian data pemrosesan input gambar yang telah di buat di laptop menggunakan software processing IDE 3.0. Setelah melakukan pengujian berupa memasukkan input gambar statis ke dalam haar cascade claseifier dengan data input pixel yang berbeda yaitu menggunakan gambar dengan resolusi 320x240 terdapat 7 mobil yang terdeteksi 6 mobil, sedangkan dengan input gambar dengan resolusi $640 \times 360$ terdapat 40 mobil yang terdeteksi 22.

Saat kendaraan dalam posisi tertutup seperti pada gambar 14 dengan mobil lainnya maka proses klasifikasi tidak bisa mendeteksi dengan tepat atau bisa tidak terdeteksi sebagai mobil, berbeda dengan input pada gambar 13 posisi gambar mobil memiliki jarak sehingga kesalahan deteksi bisa berkurang.

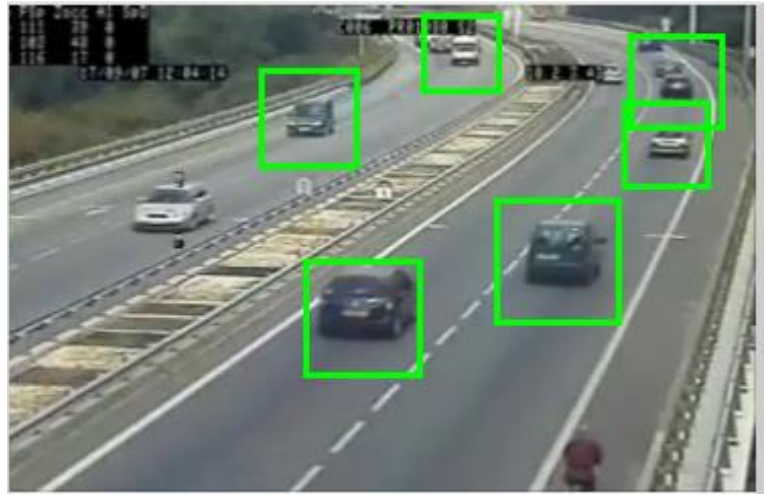

Gambar 13. Data deteksi dengan gambar 320x240

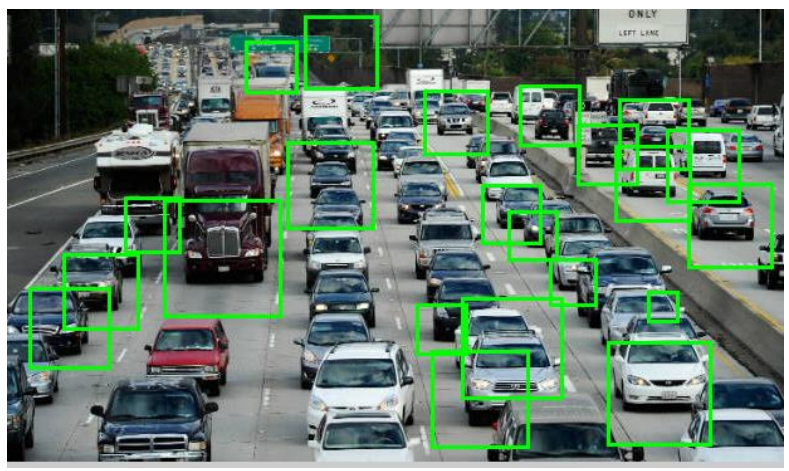

Gambar 14. Data deteksi dengan gambar 640x360

\section{Pengujian Perangkat ESP8266 Untuk Pembacaan Tegangan Baterai}

Tabel 2 .

Tabel pengukuran tegangan ESP8266

\begin{tabular}{cccc}
\hline \hline No & $\begin{array}{c}\text { Pengukuran } \\
\text { multimeter (v) }\end{array}$ & $\begin{array}{c}\text { Pembacaan ADC } \\
\text { ESP8266 (v) }\end{array}$ & Error \% \\
\hline 1 & 7.08 & 7.05 & 0.423 \\
2 & 8.02 & 7.99 & 0.374 \\
3 & 9.03 & 8.97 & 0.664 \\
4 & 10.04 & 10.01 & 0.298 \\
5 & 11.04 & 11.01 & 0.271 \\
6 & 12.06 & 12.02 & 0.331 \\
7 & 13.04 & 12.99 & 0.383 \\
8 & 14.06 & 14.03 & 0.213 \\
9 & 15.06 & 15 & 0.398 \\
10 & 15.5 & 15.46 & 0.258 \\
11 & 15.78 & 15.7 & 0.506 \\
\hline \hline
\end{tabular}

Pengujian dilakukan dengan memasukkan program baca ADC dan konversi nilai pembacaan ADC ke tegangan ke dalam memory flash mikrokontroller ESP8266. Setelah itu menghubungkan pin output dari rangkaian pembagian tegangan ke pin ADC0 dari mikrokontroller ESP 8266. Selanjutnya menampilkan secara serial ke terminal hasil konversi pembacaan $\mathrm{ADC}$ ke tegangan input, terakhir adalah membandingkan hasil pembacaan ADC dengan pengukuran tegangan menggunakan multimeter.

Dari data hasil pengujian dapat dilihat bahwa pembacaan ADC dari mikrokontroller esp8266 memiliki kepresisian yang bagus dengan error pembacaan di bawah $1 \%$ sehingga bisa disimpulkan hampir sama dengan pengukuran langsung menggunakan multi meter, hal ini karena esp8266 memiliki resolusi ADC 10 bit dengan tegangan input maksimal ADC adalah $1 \mathrm{~V}$ sehingga perubahan tiap bitnya memiliki kenaikan 
tegangan yang sangat kecil yaitu $0.97 \mathrm{mV}$ per bit. Sehingga untuk monitoring tegangan dari baterai solar cell charger dapat dilakukan dengan menggunkan modul board esp8266 dengan menambahkan terlebih dahulu rangkaian pembagi tegangan di sisi input dari pin ADC.

\section{Pengujian Lampu Lintas Nirkabel}

Dari data hasil pengujian dapat dilihat bahwa komunikasi nirkabel dengan xbee menggunakan topologi point to multi pont dapat di gunakan untuk kontrol lampu lalu lintas dengan jarak master komunikasi nirkabel dengan setiap slave atau penerima adalah 100 meter, penambahan eksternal antena omnidirectional sangat berpengaruh untuk jarak jangkauan. Waktu hijau setiap fase sesuai dengan waktu yang telah di masukkan di kontrol utama lampu lalu lintas.

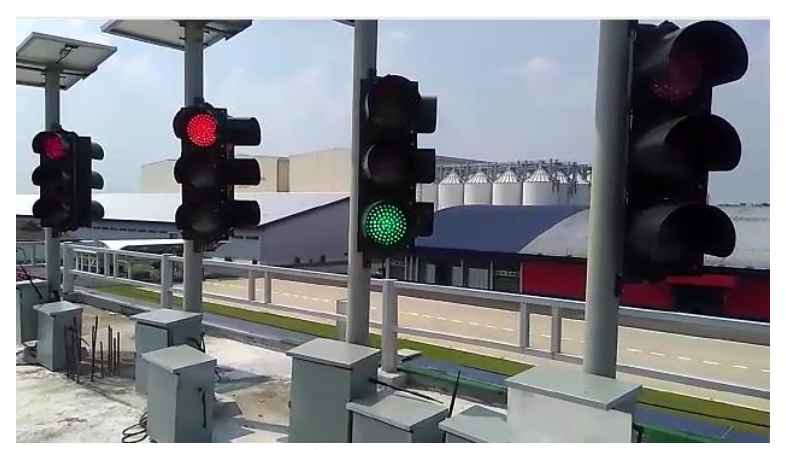

Gambar 15. Lampu Hijau fase 2 Menyala

\section{KESIMPULAN}

Setelah melakukan pengujian sistem dapat diambil beberapa kesimpulan bahwa Xbee-pro dengan frekuensi $2.4 \mathrm{Ghz}$ dapat digunakan sebagai media komunikasi nirkabel untuk mengirimkan data kondisi lampu lalu lintas di setiap persimpangan dengan menggunakan topologi point to multi point, dengan pengujian line of sight atau tanpa halangan di kondisi outdor xbee dengan pengujian maksimal jarak 100 meter data tidak ada yang hilang, dengan penambahan exsternal antena omnidirectional dapat mempengaruhi proses komunikasi menjadi lebih jauh lagi dan lebih reliable, dalam proses pengiriman xbee membuthkan konsumsi arus yang bertambah dari pada saat kondisi idle yaitu saat jarak komunikasi 100 meter arus yang di konsumsi adalah $140 \mathrm{~mA}$. Pembacaan ADC ESP8266 untuk pengukuran nilai tegangan baterai solar cell dapat di lakukan dengan menambahakan rangkaian pembagi tegangan terlebih dahulu. Dengan error pembacaan tegangan dengan pengukuran menggunakan multimeter adalah dibawah $1 \%$. Traffic light controller dapat digunakan sebagai media kontrol lampu lalu lintas baik secara skuensial (manual) dan otomatis dengan input camera. Penggunaan algoritma haar cascade classifier untuk mendeteksi ada atau tidaknya kendaraan dan menghitung banyak kendaraan dapat digunakan dengan error pembacaan saat kondisi antrian adalah mencapai $45 \%$ untuk input gambar statis. Dan saat kondisi tidak dalam antrian memiliki error $14 \%$ untuk input gambar statis.

\section{DAFTAR PUSTAKA}

[1] Khalilm. Yousef, jamaln. Al-karaki, and alim. Shatnawi "Intelligent Traffic Light Flow Control System Using Wireless Sensors Networks", , Department of Computer Engineering, Jordan University of Science and Technology

[2] Pedoman Kapasitas Simpang APILL, Kementerian Pekerjaan Umum Tahun 2014

[3] Mohamed Amine KAFI, Yacine CHALLAL, Djamel DJENOURI, Abdelmadjid BOUABDALLAH, Lyes KHELLADI, Nadjib BADACHE, "A study of Wireless Sensor Network Architectures and Projects for Traffic Light Monitoring", Université de Technologie de Compiègne, Laboratoire Heudiasyc UMR CNRS 6599, France

[4] R. Lienhart and J. Maydt. "An Extended Set of Haar-like Features for Rapid Object Detection". IEEE ICIP 2002, Vol. 1, pp. 900-903, Sep. 2002.

[5] M. Oliveira, V. Santos, "Automatic Detection of Cars in Real Roads using Haar-like Features", Department of Mechanical Engineering, University of Aveiro, 3810 Aveiro, Portugal 